\title{
Hemobilia Induced by Gall Bladder Polyps
}

\author{
Reza Nazarzadeh ${ }^{1}$, Saeedeh Majidi ${ }^{*}$, Parya Dehghanian², Ali Alamdaran ${ }^{3}$ and Mehran Hiradfar ${ }^{4}$ \\ ${ }^{1}$ Department of Pediatric Surgery, Mashhad University of Medical Science, Iran \\ ${ }^{2}$ Department of Pathology, Akbar Hospital \& Mashhad University of Medical Science, Iran \\ ${ }^{3}$ Department of Radiology, Akbar Hospital \& Mashhad University of Medical Science, Iran \\ ${ }^{4}$ Endoscopic and Minimally Invasive Surgery Research Center, Mashhad University of Medical Science, Iran
}

Submission: June 18, 2019; Published: July 11, 2019

*Corresponding author: Saeedeh Majidi, Department of Pediatric Surgery, Mashhad University of Medical Science, Mashhad, Iran

\begin{abstract}
Hemobilia is an aberrant connection of hepatic biliary and vascular systems. It usually occurs post traumatic, blunt trauma or iatrogenic. Non traumatic hemobilia is a rare occurrence which there are few case reports in children which were due to pancreatic pseudocyst, choledochal cyst, hepatic abscess, hepatic fascioliasis and Meta chromatic leukodystrophy. All reported cases are female except one with von Willebrand's disease. In few patients Meta chromatic leukodystrophy (MLD) was the cause of hemobilia. MLD is a rare neurological disease which is caused by Sulfatids deposition in nervous tissue and it has three subtypes, late infantile, juvenile and adult type. The gall bladder may be involved in the disease course and presents with different symptoms like abdominal pain or hemobilia. We present an eight-year-old girl with late infantile MLD who presented with upper GI bleeding and in evaluation the diagnosis of hemobilia and gall bladder polyps was confirmed.
\end{abstract}

Keywords: Hemobilia; Tissue hyperplasia; Metachromatic leukodystrophy; Blunt trauma; Abdominal pain

\section{Introduction}

Gall bladder polyps are tissue hyperplasia, which protrude inside the gall bladder from the inner surface. They may be found accidentally or present with vague abdominal pain and vomiting. GBPs are rare in general population and are even less common in pediatric age group [1].

The most important cause of gallbladder polyps in children is Metachromatic Leukodystrophy (MLD). MLD is a lysosomal storage disease, which progressively affects central and peripheral nervous system. It has three sub types based on the age of manifestation onset. In late infantile subtype, the child development is normal in the first 2 years. Neurological impairment and developmental delay manifest after this period [2].

Gallbladder involvement in MLD is a known condition, which may have no significant symptoms or present with different manifestations such as abdominal pain, vomiting or upper GI bleeding. Hemobilia due to MLD is a rare entity. We present a child with MLD with neurological impairment who was admitted with massive hematemesis due to Gallbladder polyps.

\section{Case}

An eight-year-old girl referred to emergency ward of Akbar Hospital with melena and massive hematemesis, which started since 12 hours ago. She was a known case of Metachromatic Leukodystrophy (MLD) since the age of 4 years.

Physical examination revealed Pale conjunctiva. No abdominal tenderness or mass was palpable. Vital signs at the time of admission were: Blood pressure $=100 / 60 \mathrm{mmHg}$, pulse rate $=$ $120 /$ min with normal respiratory rate and temperature. The hemoglobin dropped to 7.5 from $11.5 \mathrm{gr} / \mathrm{Dl}$ during transporting from first local hospital.

She was the first child of consanguineous parents with history of term delivery and her birth weight was 3900 grams. She experienced normal development until about two years of age, then she gradually showed developmental delay, regression of speech and ability of walking and seizure attacks occurred.

At the age of three, she was not able to walk due to muscle spasm with loss of DTR and no Babinski reflex. Verbal skill was lost, and hearing tests showed auditory impairment. 


\section{Juniper Online Journal of Case Studies}

Sensorimotor (demyelinating) type of peripheral neuropathy was shown in EMG study. In brain MRI there was extensive signal abnormality in both centrum semi-oval with sparing subcortical U-fibers. Typical involvement of the corpus callosum and brain stem was present (Figure 1A). In MR Spectroscopy, increase in Choline was suggestive of active myelin breakdown, which is compatible with the diagnosis of MLD. In addition, lactate rise was reported in MR spectroscopy, which was related to ischemia and necrotic component.

US showed thickened calcified irregular gallbladder wall and multiple polypoid lesions in gallbladder. GB was filled with blood. Two intraluminal cystic lesions were also reported in gallbladder fundus (Figure 1B \& 1C).
After stabilizing the vital signs and transfusion of blood, upper GI endoscopy was performed which showed active bleeding coming through the orifice of ampulla of Vater. Due to persistent bleeding and hematochezia, exploratory celiotomy and cholecystectomy was performed. External biliary tract was washed-out by-passing catheter through cystic duct that was filled with blood.

Gross pathology examination revealed that the gallbladder was distended with multiple intramural yellowish lesions in cut surface of GB (Figure 1D \& 1E). Microscopic study revealed mucosal papillary thickening and presence of foam cells in subepithelial stroma with focal low-grade intraepithelial dysplasia (Figure 1F).

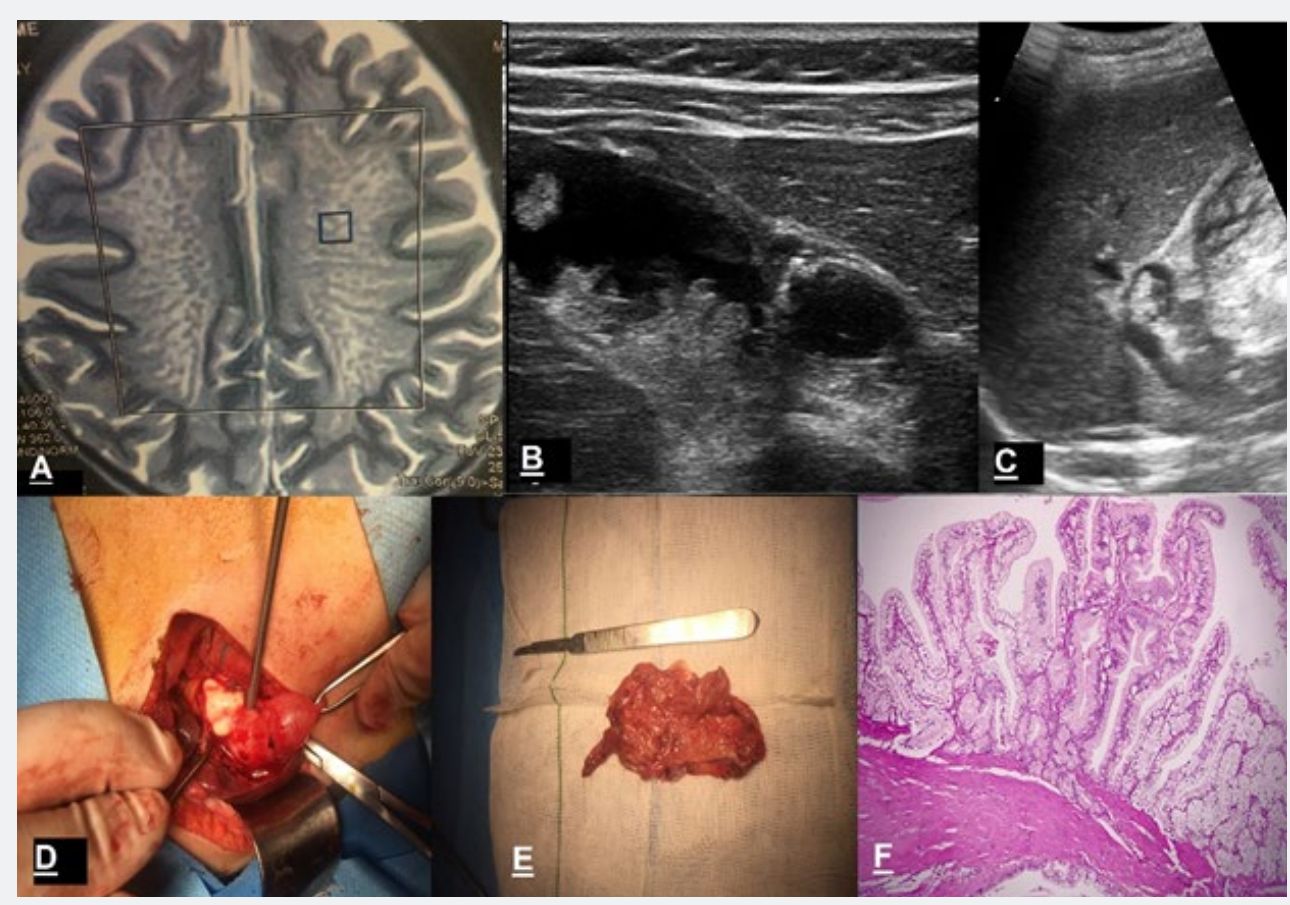

Figure 1: A) Axial T2 Brain MRI shows abnormal symmetric central white matter hyperintensity with sparing of $U$ fibers.

B) The ultrasonography images. The longitudinal view of gallbladder with irregular and thick wall of gallbladder and multiple polypoid lesions and oval cystic lesion associated with calcified wall.

C) Echogenic clot in hilar bile duct.

D, E) Intra-operative view of gall bladder and gross mucosal view.

F) gall bladder with marked mucosal thickening and papillary fronds lined by pale amphophilic epithelial cells, also presence of foam cells in the subepithelial stroma; in a patient with metachromatic leukodystrophy.

Oral intake was started the day after operation. Melena stopped about 4 days later. Patient discharged home with no episode of recurrent bleeding.

\section{Discussion}

Hemobilia is a rare condition in general population which occurs in $2.5 \%$ of patients after blunt liver trauma and in $3 \%$ $7 \%$ after hepatobiliary [3]. Hemobilia in children is even rarer and usually occurs after blunt abdominal trauma. This is due to communication between aneurysm in hepatic arteries and the biliary tract and may become a life-threatening condition with $25 \%$ mortality rate. Selective hepatic artery embolization is an appropriate treatment for this condition [4].

Other causes of hemobilia in adults include infection or stone [5]. There are some case reports of non-traumatic hemobilia in children that are mentioned in Table 1. All of them except one with von willebrand disease were female. Severe anemia reported as a hallmark of clinical presentation in nearly all of cases. Due to continuous and profuse bleeding, blood transfusion was done in most of cases. 
Table 1: Non-traumatic hemobilia in children.

\begin{tabular}{|c|c|c|c|c|c|c|c|c|c|}
\hline Author & $\begin{array}{l}\text { Age } \\
\text { Sex }\end{array}$ & Symptoms & Transfusion & $\begin{array}{l}\mathrm{Hb}(\mathrm{g} / \\
\text { dl) }\end{array}$ & U.S. & C.T Scan & Surgery & Endoscopy & Pathology \\
\hline \multirow{2}{*}{$\begin{array}{c}\text { Bairagi \& } \\
\text { Aronson } \\
\text { [5] }\end{array}$} & $4 y \mathrm{f}$ & $\begin{array}{c}\text { Hematemesis \& } \\
\text { melena. 1week }\end{array}$ & yes & 7.1 & $\begin{array}{c}\text { A } 4 \times 4 \mathrm{~cm} \\
\text { heterogeneous mass }\end{array}$ & $\begin{array}{l}\text { Large } \\
\text { pseudo } \\
\text { aneurysm } \\
\text { of splenic } \\
\text { artery }\end{array}$ & $\begin{array}{c}\text { Distal } \\
\text { pancreatectomy } \\
\text { with cyst resection } \\
+ \text { splenic artery } \\
\text { ligation }\end{array}$ & $\begin{array}{l}\text { Blood at the } \\
\text { ampulla of Vater } \\
\text { and floor of the } \\
\text { duodenum }\end{array}$ & $\begin{array}{l}\text { Pancreatic } \\
\text { pseudocyst }\end{array}$ \\
\hline & $11 \mathrm{yf}$ & $\begin{array}{l}\text { Jaundice, } \\
\text { hematemesis, } \\
\text { melena. } 1 \\
\text { month }\end{array}$ & yes & 4.2 & $\begin{array}{c}\text { Abnormal hepatic } \\
\text { echo + dilated } \\
\text { intrahepatic dust and } \\
\text { portal vein }\end{array}$ & $\begin{array}{l}\text { Enlarged } \\
\text { gallbladder } \\
+ \text { irregular } \\
\text { biliary tree }\end{array}$ & Hepaticojejunostomy & $\begin{array}{l}\text { Bleeding from } \\
\text { ampulla of } \\
\text { Vater }\end{array}$ & $\begin{array}{l}\text { Choledochal } \\
\text { cyst }\end{array}$ \\
\hline $\begin{array}{l}\text { Wanner, } \\
\text { Karmazyn } \\
{[6]}\end{array}$ & $\begin{array}{l}4 y \mathrm{~F} \\
\text { (MLD) }\end{array}$ & $\begin{array}{c}\text { Abdominal } \\
\text { pain \& massive } \\
\text { hematemesi. } \\
1 \text { day }\end{array}$ & yes & 7.1 & $\begin{array}{l}\text { A polypoid vascular } \\
\text { mass at the } \\
\text { gallbladder fundus }\end{array}$ & $\begin{array}{l}\text { Dilation } \\
\text { of biliary } \\
\text { tree }+ \\
\text { gallbladder } \\
\text { mass }\end{array}$ & Cholecystectomy & $\begin{array}{l}\text { Active bleeding } \\
\text { from the } \\
\text { ampulla of } \\
\text { Vater }\end{array}$ & $\begin{array}{c}\text { MLD the mass } \\
\text { was a villous } \\
\text { papilloma } \\
\text { with a mild } \\
\text { degree of } \\
\text { dysplasia }\end{array}$ \\
\hline $\begin{array}{c}\text { Khalil, } \\
\text { Chadha [7] }\end{array}$ & - & - & - & - & Liver abscess & - & $\begin{array}{l}\text { Selective arterial } \\
\text { embolization }\end{array}$ & - & Liver abscess \\
\hline $\begin{array}{l}\text { Awasthy, } \\
\text { Juneja [8] }\end{array}$ & $11 \mathrm{yf}$ & $\begin{array}{l}\text { Abdominal } \\
\text { pain, fever, } \\
\text { hematemesis, } \\
\text { melena. }\end{array}$ & yes & 3.8 & $\begin{array}{l}\text { A } 3 \times 2.5 \mathrm{~cm} \text { abscess in } \\
\text { the right lobe of liver } \\
+ \text { blood clots in the } \\
\text { gall bladder }\end{array}$ & - & $\begin{array}{l}\text { Selective coil } \\
\text { embolization }\end{array}$ & $\begin{array}{l}\text { Communication } \\
\text { of the biliary } \\
\text { radicals with } \\
\text { the hepatic } \\
\text { artery in ERCP } \\
\end{array}$ & Liver abscess \\
\hline $\begin{array}{l}\text { Kaneko, } \\
\text { Ando [9] }\end{array}$ & $2 \mathrm{yf}$ & $\begin{array}{l}\text { Recurrent } \\
\text { hemobilia }\end{array}$ & - & - & - & - & $\begin{array}{l}\text { Left hepatectomy } \\
\text { and excision of the } \\
\text { duplication were } \\
\text { curative }\end{array}$ & $\begin{array}{c}\text { Gastric } \\
\text { duplication that } \\
\text { communicated } \\
\text { with the left } \\
\text { hepatic duct }\end{array}$ & $\begin{array}{l}\text { Gastric } \\
\text { duplication }\end{array}$ \\
\hline $\begin{array}{c}\text { Garavelli, } \\
\text { Rosato [10] }\end{array}$ & $\begin{array}{c}5 y \mathrm{~F} \\
\text { (MLD) }\end{array}$ & $\begin{array}{c}\text { Hematemesis \& } \\
\text { melena. } 1 \text { day }\end{array}$ & yes & 7.1 & - & - & Cholecystectomy & $\begin{array}{l}\text { Active bleeding } \\
\text { from the } \\
\text { ampulla of } \\
\text { Vater }\end{array}$ & $\begin{array}{l}\text { MLD yellow } \\
\text { polypoid } \\
\text { lesion of } 2 \mathrm{~cm} \\
\text { in gallbladder } \\
\text { and wall } \\
\text { thickening }\end{array}$ \\
\hline $\begin{array}{l}\text { Kaafarani, } \\
\text { Taher [11] }\end{array}$ & $14 \mathrm{y} \mathrm{m}$ & $\begin{array}{l}\text { Abdominal } \\
\text { pain. } 1 \text { week }\end{array}$ & & 11.6 & $\begin{array}{c}\text { Distended gallbladder } \\
\text { with thickened wall } \\
\text { and intraluminal } \\
\text { blood clot. CBD was } \\
1.0 \mathrm{~cm}\end{array}$ & $\begin{array}{l}\text { Intra gall } \\
\text { bladder } \\
\text { blood clot }\end{array}$ & $\begin{array}{c}\text { Factor VIII } \\
\text { replacement } \\
\text { Extracting blood clot } \\
\text { with ERCP + bile duct } \\
\text { stenting }\end{array}$ & $\begin{array}{l}\text { (ERC) revealed } \\
\text { impacted blood } \\
\text { clot at the } \\
\text { orifice of the } \\
\text { major duodenal } \\
\text { papilla }\end{array}$ & $\begin{array}{c}\text { Von } \\
\text { Willebrand's } \\
\text { disease }\end{array}$ \\
\hline $\begin{array}{c}\text { Almendras- } \\
\text { Jaramillo, } \\
\text { Rivera- } \\
\text { Medina } \\
\text { [12] }\end{array}$ & $6 \mathrm{Y} \mathrm{M}$ & $\begin{array}{c}\text { Fever \& } \\
\text { hematemesis }\end{array}$ & - & - & - & - & Bithionol & Hemobilia & $\begin{array}{l}\text { Identification } \\
\text { of hepatic } \\
\text { fascioliasis } \\
\text { eggs in the } \\
\text { feces }\end{array}$ \\
\hline
\end{tabular}

Metachromatic Leukodystrophy (MLD) is a main cause of gallbladder polyps and non-traumatic hemobilia in children, which is a rare lysosomal disease that has autosomal recessive inheritance. MLD is due to deficiency in Arylsulfatase A (ARSA) enzyme which causes accumulation of sulfatides especially in nervous tissue. This induces progressive lethal demyelinating process [13].

MLD should be suspected in a patient with progressive neurological disorder and developmental retardation. Brain MRI findings show evidence of leukodystrophy that become more prominent culminating in cerebral atrophy with progression of the disease. Confirmation of diagnosis is by detection of biallelic
Arylsulfatase A (ARSA) pathologic variant on genetic test, increased sulfatide excretion in urine or detecting metachromatic deposition in tissue biopsy of nervous system or affected viscera.

Based on the time of occurrence of the first symptoms, MLD has three subtypes. It consists of "late infantile", "juvenile" and "adult" forms. Patients in the late infantile subgroup, like the reported case, show neurologic symptoms usually before 30 months of age [2]. This subgroup involves 50\%- $60 \%$ of all affected individuals and has the worst course and prognosis. Most patients $(61 \%)$ of this group present with gait abnormalities and seizures (39\%) [14]. 
Association of MLD and gallbladder abnormalities has been reported in literature and Gallbladder involvement seems to be a rule. In addition, it can present before the main neurological symptoms and may be key to the diagnosis of MLD $[15,16]$. Pathologic evaluation shows different abnormalities such as hyperplastic polyps, metaplasia, dysplasia, sulfatides accumulation and metachromatic stain [17], villous hyperplasia [18] and even neoplastic changes.

\section{Conclusion}

Gallbladder involvement MLD disease usually presents with abdominal pain, vomiting or jaundice. Data search revealed hemobilia in only four cases of MLD $[6,10,19,20]$. Presence of GIB in MLD cases mandate evaluation of the biliary tract.GB is the first culprit in this scenario.

\section{References}

1. Andrén-Sandberg Å (2012) Diagnosis and management of gallbladder polyps. N Am J Med Sci 4(5): 203-211.

2. Fluharty A (1993) Arylsulfatase A deficiency.

3. Wani NA, Gojwari TA, Khan NA, Kosar TL (2011) Hemobilia in a child due to right hepatic artery pseudoaneurysm: multidetector-row computed tomography demonstration. Saudi J Gastroenterol 17(2): 152-154.

4. Läckgren G, Lörelius LE, Olsen L, Wassén C (1988) Hemobilia in childhood. J Pediatr Surg 23(2): 105-108.

5. Bairagi A, Aronson DC (2015) Nontraumatic hemobilia in children European J Pediatr Surg Rep 3(1): 23-26.

6. Wanner MR, Karmazyn B, Fan R (2015) Multidetector CT diagnosis of massive hemobilia due to gallbladder polyposis in a child with metachromatic leukodystrophy. Pediatr Radiol 45(13): 2017-2020.

7. Khalil A, Chadha V, Mandapati R, Mathur N, Mittal S, et al. (1991) Hemobilia in a child with liver abscess. J Pediatr Gastroenterol Nutr 12(1): $136-138$

8. Awasthy N, Juneja M, Talukdar B, Puri AS (2007) Hemobilia Complicating a Liver Abcess. Journal of Tropical Pediatrics 53(4): 278279
9. Kaneko K, Ando H, Watanabe Y, Seo T, Harada T, Ito F (1999) Gastric duplication communicating with the left hepatic duct: A rare case of recurrent hemobilia in a child. J Pediatr Surg 34(10): 1539-1540.

10. Garavelli L, Rosato S, Mele A, Wischmeijer A, Rivieri F, et al (2009) Massive hemobilia and papillomatosis of the gallbladder in metachromatic leukodystrophy: a life-threatening condition. Neuropediatrics 40(6): 284-286.

11. Kaafarani H, Taher A, Haddad MC, Haidar A, Mourad FH (2003) Spontaneous intracholecystic bleeding in a patient with von Willebrand's disease. Gastrointest Endosc 58(5): 809-811.

12. Jaramillo MA, Medina JR, Mogrovejo JS, Jaramillo KA (1997) Hepatic fascioliasis in children: uncommon clinical manifestations. Arq Gastroenterol 34(4): 241-247.

13. Gieselmann V, Zlotogora J, Harris A, Wenger DA, Morris CP (1994) Molecular genetics of metachromatic leukodystrophy. Hum Mutat 4(4): 233-242.

14. Mahmood A, Berry J, Wenger DA, Escolar M, Sobeih M, et al. (2010) Metachromatic leukodystrophy: a case of triplets with the late infantile variant and a systematic review of the literature. J Child Neurol 25(5): 572-580.

15. Ries M, Deeg KH (1993) Polyposis of the gallbladder associated with metachromatic leukodystrophy. Eur J Pediatr 152(5): 450-451.

16. Shah S, Ghosh S, Nagarajan L (2013) Leukodystrophy: when gallbladder offers a clue to diagnosis. Pediatr Neurol 49(1): 68-69.

17. Almarzooqi S, Quadri A, Albawardi A (2018) Gallbladder Polyps in Metachromatic Leukodystrophy. Fetal Pediatr Pathol 37(2): 102-108.

18. McFadden K, Ranganathan S (2015) Pathology of the gallbladder in a child with metachromatic leukodystrophy. Pediatric and Developmental Pathology 18(3): 228-230.

19. Vettoretto N, Giovanetti M, Regina P, Baronchelli C, Giulini S (2001) Hemorrhagic cholecystitis as a likely cause of nontraumatic hemobilia in metachromatic leukodystrophy: report of a case. Ann Ital Chir 72(6): 725-728.

20. Siegel E, Lücke H, Schauer W, Creutzfeldt W (1992) Repeated upper gastrointestinal hemorrhage caused by metachromatic leukodystrophy of the gall bladder. Digestion 51(2): 121-124. 